\title{
Os microdramas de Wolfgang Bauer: o riso como liberação e como provocação ${ }^{1}$
}

\author{
[The microdramas of Wolfgang Bauer: laughter as liberation and as provocation] \\ http://dx.doi.org/10.11606/1982-88372442304
}

\section{Ruth Bohunovsky²}

\begin{abstract}
At first glance, Wolfgang Bauer's microdramas, written in the 1960s, appear to be nothing more than funny little jokes about the dramatic genre and its conventions. Based on the assumption that they also had a considerable provocative - and even political - potential, especially in the conservative context of Austria in the 1960s, this article proposes a reflection about the relationship between the comical and the provocative dimensions of these texts. Based on studies of the characteristics and effects of Bauer's work (Antonic [2018; 2019]; Melzer [1981], Waggershauser [2016]), as well as Peter L. Berger's (1998) and Uwe Wirth's (1999) studies about the comical human experience, this article proposes that Bauer's microdramas are not just an example of a very innovative meta-theater. They may elicit a liberating, "redeeming" laughter that can also be felt as a political provocation, especially in social contexts marked by essentialist and/or fundamentalist discourses.
\end{abstract}

Key words: Wolfgang Bauer; microdramas; comical experience.

Resumo: À primeira vista, os microdramas de Wolfgang Bauer, escritos nos anos 1960, parecem ser nada mais do que pequenas brincadeiras engraçadas com o gênero dramático e suas convenções. Partindo da constatação que eles tiveram um considerável efeito provocativo, e até político, no contexto conservador da Áustria daquela década, propõe-se uma reflexão sobre a relação entre a sua comicidade e o seu potencial incitador. Com base em estudos sobre características e efeitos da obra de Wolfgang Bauer (Antonic [2018; 2019]; Melzer [1981], Waggershauser [2016]) e nas teorizações sobre a experiência do cômico de Peter L. Berger (1998) e Uwe Wirth (1999), este artigo sugere que os microdramas de Bauer não são apenas um exemplo de metateatro bastante inovador. Eles permitem surgir um riso "redentor", libertador, que também pode ser sentido como uma provocação política, especialmente em contextos sociais marcados por discursos essencialistas e/ou fundamentalistas.

Palavras-chave: Wolfgang Bauer; microdramas; cômico.

\footnotetext{
${ }^{1} \mathrm{O}$ presente artigo foi elaborado no âmbito do projeto de pesquisa "Traduzir o teatro e o cômico: formas e funções do cômico em textos teatrais contemporâneos da Áustria", contemplado com uma bolsa de pesquisa Franz Werfel do ÖAD (Serviço de Intercâmbio Austríaco) para a realização de um pós-doutorado nas universidades de Viena e Graz (março de 2019 até fevereiro de 2020).

${ }^{2}$ Universidade Federal do Paraná, Departamento de Polonês, Alemão e Letras Clássicas, Rua XV de Novembro, 1299, Curitiba, PR, 80060-000, Brasil. E-mail: ruth.bohunovsky@ gmail.com. ORCID: 00000003-4412-2678
}

\section{(c)) BY-NC}

Pandaemonium, São Paulo, v. 24, n. 42, jan.-abr. 2021, p. 304-332 
Bohunovsky, R. - Os microdramas de Wolfgang Bauer

Fundamentalistas não têm humor.

Paul Chaim Eisenberg, rabino-chefe de Viena ${ }^{3}$

Wolfgang Bauer foi um autor muito sério, caso contrário não poderia ter tido um efeito tão cômico.

Elfriede Jelinek ${ }^{4}$

\section{Introdução}

No começo dos anos 1960, a Áustria era um país extremamente conservador, marcado por discursos oficiais carregados de um moralismo retrógrado e patriarcal, fundamentados em uma política cultural em prol da construção de uma identidade nacional e que tentavam livrar a nação de qualquer culpa relacionada aos crimes da Segunda Guerra Mundial. Produções culturais críticas ou da vanguarda ainda costumavam ser avaliadas com terminologia e conceitos nazistas. Mesmo assim, existiam alguns grupos e artistas que conseguiam criar uma arte de vanguarda, de influência surrealista e dadaísta e de inovação literária e linguística, como por exemplo, o Wiener Gruppe [Grupo de Viena], desde 1954, ou os Wiener Aktionisten [Acionismo Vienense], a partir dos anos 1960.

Foi nessa época que Wolfgang Bauer (1941-2005) iniciou sua carreira artística. Em fevereiro de 1961, com apenas 20 anos, assistiu em Graz à peça Rhinocéros [O rinoceronte] de Éugene Ionesco, escrita em 1959. Ainda na mesma noite, iniciou a redação de sua primeira peça, Der Schweinetransport [O transporte de porcos] (ANTONIC 2018: 34), sob forte impressão da obra recém-vista, que é emblemática para o "teatro do absurdo" - vertente à qual Bauer foi associado posteriormente (ESSLIN 2006). Essa primeira peça do dramaturgo novato abre com um riso - que é, ao mesmo tempo, uma provocação. Um dos três personagens é Der Lacher [Aquele que ri], na versão final reduzido para L; e é a ele que cabe a primeira emissão sonora no palco: "L: lacht laut" [L: ri alto]. Pouco depois, o riso de $\mathrm{L}$ interrompe um diálogo entre os personagens $\mathrm{S}$ (originalmente: "Aquele que não cheira nada" [Der, der nichts riecht $]$ ) e $\mathrm{H}$ (originalmente: “Aquele que não vê nada e que escuta errado" [Der, der nichts sieht und falsch hört]):

\footnotetext{
${ }^{3}$ Comunicação oral feita no Alte Schmiede em Viena em 16 de dezembro de 2019; no original: Fundis haben keinen Humor. Todas as traduções citadas neste artigo são de minha autoria, salvo informação contrária.

${ }^{4}$ Jelinek 2011: 9. No original: "Wolfgang Bauer war ein sehr ernster Autor, sonst hätte er nicht so komisch wirken können".

Pandaemonium, São Paulo, v. 24, n. 42, jan.-abr. 2021, p. 304-332
} 
Bohunovsky, R. - Os microdramas de Wolfgang Bauer

H: Por que você está rindo? Seu nada!

L: Eu rio, porque não sou. $-R i$.

$\mathrm{H}$ : Apenas aqueles que são podem rir!

L: Muito pelo contrário, apenas aqueles que não são mais podem rir, haha! Vocês são, portanto vocês não podem rir!

S: Claro que podemos rir.

L: Então riam... riam de mim... riam, riam! Haha! Podem tentar... sou todo ouvidos... E daí? O que foi?

H: Agora não estou a fim de rir $^{5}$. (BAUER 1987: 18)

Permite-se a seguinte interpretação: aqueles que "são" chamam L de um "nada", colocando-se assim numa posição de suposta superioridade; ao mesmo tempo, irritam-se com seu riso, questionando sua legitimidade e o direito de rir. O motivo da irritação dos dois antagonistas de L não fica claro, mas entende-se que L não ri de $\mathrm{H}$ e $\mathrm{S}$, seu riso tem outro motivo. Certo também é que L, partindo de uma posição marginal ("não sou") em relação àqueles que "são", não só profere uma versão subversiva ("Rio, porque não sou") do dogma cartesiano e emblema da racionalidade moderna: Cogito, ergo sum, como se revela o único capaz de rir. As tentativas daqueles que "são" resultam em fracasso. Segundo a rubrica (BAUER 1987: 18), acontecem apenas algumas "tentativas abafadas de riso" por parte de H e L. Surge assim a impressão de que há dois grupos de personagens: aqueles que "são" (dominantes), mas não conseguem rir, e aqueles que "não são", mas são capazes de rir. Tal divisão já nos aproxima da argumentação que será apresentada ao longo deste artigo.

Não apenas os personagens das peças de Bauer se dividem em grupos antagônicos: os que conseguem rir e aqueles que não possuem essa capacidade. Parte do público de Bauer reagiu com risos e gargalhadas ao que viu e ouviu - já outra parte se sentiu ofendida e na obrigação de expor seu descontentamento em cartas publicadas em jornais. Thomas Antonic, autor de diversos estudos recentes sobre a obra de Bauer, cita (2017: 2) algumas passagens dessas cartas em que leitores chamam as peças do dramaturgo austríaco de uma “evacuação de cloacas espirituais” e defendem até sua execução, "uma vez como diretor teatral, duas vezes como autor”. A mesma divisão ocorreu no âmbito da crítica

\footnotetext{
${ }^{5}$ No original: H: Weshalb lachen Sie? Sie Nichts! - L: Ich lache, weil ich nicht bin. Lachen - H: Nur Seiende können lachen! - L: Im Gegenteil, nur mehr Nicht-Seiende können lachen, haha, Sie sind, Sie können daher auch nicht lachen! - S: Und ob wir lachen können. L: So lacht doch ... lacht mich aus ... lacht, lacht! Haha! Versucht es doch ... ich lausche ... na? Was ist? - H: Ich will jetzt nicht lachen.
}

Pandaemonium, São Paulo, v. 24, n. 42, jan.-abr. 2021, p. 304-332 
Bohunovsky, R. - Os microdramas de Wolfgang Bauer

especializada. A avaliação de Paul Pechmann (2008: 11), organizador de uma coletânea de textos sobre Bauer, é sintomática nesse sentido:

A pergunta repetida frequentemente em ocasião de estreias de peças [de Wolfgang Bauer] - será que é arte ou palhaçada [Klamauk] aquilo que vemos no palco? - tem sido respondida pela crítica especializada com a segunda opção. A relação descomplicada que Bauer teve com tudo que abrange nossa realidade trivial de vida e mediática, sua prática de incorporar na "alta" literatura, de modo natural e sem tom denunciador, o banal, o grosseiro-cômico e outros "maus comportamentos" - que transgridem o common sense da burguesia culta [Bildungsbügertum] -, e mais: de tornar tudo isso a matéria-prima de sua arte é motivo de suspeita para a taxonomia da alta cultura autossuficiente.

Os microdramas, enfoque do presente artigo, marcaram o início dessa tendência na recepção da obra de Bauer. O exemplo mais famoso das diversas tentativas de desacreditar o nome de Bauer como um literato de relevância foram as avaliações da renomada crítica literária Sigrid Löffler, que escolheu Bauer como seu "inimigo predileto" (ANTONIC 2018: 222), associando a comicidade em sua obra com uma suposta idiotice e falta de conteúdo. Por exemplo, sobre Herr Faust spielt Roulette [O senhor Fausto joga roleta], de 1986, Löffler escreveu na revista Profil em 2 de fevereiro de 1987: "A peça de Bauer [...] não faz de conta que é estúpida, ela é estúpida" (WAGGERSHAUSER 2016: 21). Menos negativa, mas igualmente representativa, foi a avaliação de Benjamin Henrichs num artigo no jornal Süddeutsche Zeitung em 19 de abril de 1971, em que chama Bauer de "o autor trivial mais cômico da Alemanha (e da Áustria)"6 (MELZER 1978: 16).

Em 1981, Gerhard Melzer publicou o primeiro grande estudo sobre Bauer naquela época já um dramaturgo de sucesso internacional entre o público - com o objetivo explícito de contribuir para uma "correção" de clichês e leituras tendenciosas que procuravam reduzir seu papel ao de um escritor cômico, banal e "dialetal” (MELZER 1981: 7). É interessante notar que nesse livro Melzer sequer aborda o potencial cômico da obra baueriana, nem mesmo em relação aos microdramas (um exemplo proeminente da dimensão cômica na obra desse dramaturgo, como veremos mais adiante). Melzer parece ter procurado valorizar outros aspectos (como o potencial de inovação estética, as reflexões de teor filosófico), no intuito de aproximar a obra de Bauer das expectativas dominantes no âmbito do "common sense da burguesia culta", para repetir a expressão usada por Pechmann (2008: 11).

\footnotetext{
${ }^{6}$ Não fica claro por que razão Henrichs associa Bauer à literatura da Alemanha, colocando a menção à Áustria apenas entre parênteses.

Pandaemonium, São Paulo, v. 24, n. 42, jan.-abr. 2021, p. 304-332
} 
Bohunovsky, R. - Os microdramas de Wolfgang Bauer

Em estudos mais recentes encontramos um cenário diferente, no qual a dimensão cômica da obra de Bauer e, em especial, dos microdramas não é mais vista como um obstáculo ao seu reconhecimento artístico. Partindo de tal visão, é propósito deste artigo dar um passo adiante e contribuir para se entender o cômico identificado nos microdramas como parte fundamental da poética de vanguarda do autor, como um modo de expressar determinados objetivos político-filosóficos e, devido à maneira peculiar com que Bauer consegue agregar esses fatores, também como o elemento responsável pela relevância artística da obra se estender até os dias atuais.

Horst Waggershauser (2016) partiu justamente da constatação da inexistência de qualquer discussão sobre a comicidade no livro de Melzer e definiu como foco de seu estudo a relação entre vanguarda e comicidade na obra de Bauer. Thomas Antonic (2018: 353 , 394) lamenta repetidamente o fato de a comicidade ter sido muito mais um empecilho do que um aspecto favorável para a recepção da obra de Bauer, pelo menos no âmbito crítico e acadêmico de língua alemã. Aliás, o próprio Wolfgang Bauer se posicionou diversas vezes de modo bastante crítico contra aquilo que identificou como uma tradição dos países de língua alemã, a praxe de evitar relacionar temas sérios e/ou filosóficos com o cômico. Segundo Bauer, seria justamente esta uma característica central de sua obra e ela sempre teria ajudado na recepção de sua obra em outros países, como nos Estados Unidos e na Espanha (ANTONIC 2018: 353, 394).

Entre 1962 e 1964, pouco depois de compor seus primeiros dramas curtos, Bauer escreveu 21 miniaturas dramáticas ${ }^{7}$. Extremamente reduzidas, são peças parodiando temas e personagens de dramas clássicos, de Ramsés até Haydn, dos três mosqueteiros até Richard Wagner. Trata-se de textos de grande semelhança formal, caracterizados por um alto potencial cômico e uma total falta de consideração com quase tudo que se acreditava serem convenções e normas inabaláveis no meio teatral. Antes da primeira publicação em forma de livro (1964), alguns dos microdramas já tinham saído em revistas literárias; também houve gravações de discos e de vídeos de leituras realizadas pelo próprio autor, assim como leituras públicas realizadas por Bauer na Áustria, Suíça e Alemanha. A recepção foi dividida: o público e alguns críticos e jornalistas gostaram, outros alegaram "dificuldades de compreensão", mostraram-se "irritados" (ANTONIC 2018: 104) e, ignorando a inovação poética e formal, reagiram com ironia zombando da

\footnotetext{
${ }^{7}$ Um dos microdramas, intitulado Odysseus, se perdeu e só foi encontrado em 2015.

Pandaemonium, São Paulo, v. 24, n. 42, jan.-abr. 2021, p. 304-332
} 
Bohunovsky, R. - Os microdramas de Wolfgang Bauer

brevidade das peças ${ }^{8}$. Ao mesmo tempo, muitos colegas literatos ficaram impressionados, entre eles um dos membros mais famosos do Grupo de Viena, H. C. Artmann (ANTONIC 2018: 105). O poeta Ernst Jandl escreveu uma resenha (1965: 58-59) e argumentou que se tratava de textos "explosivos", de "matéria-prima para o riso que consegue derrubar" e de uma "verdadeira poesia". Para Jandl, Bauer seria um "dramaturgo nato" que sabia usar "todos os meios do teatro" para "arrebentar todos os limites do teatro" (JANDL 1965: 58).

Numa entrevista recente, em ocasião da entrega do Prêmio Nobel de Literatura ao também austríaco Peter Handke, o cineasta Horst Dieter Sihler (2019) citou tanto os microdramas quanto a famosa peça do escritor laureado Publikumsbeschimpfung (publicada no Brasil sob o título Insulto ao público [HANDKE 2015: 81-158]) como sendo os marcos iniciais de um "novo olhar para as coisas". Segundo Sihler (2019: s.p.), os microdramas foram essenciais para confirmar a "intuição" de muitos jovens artistas em oposição aos "conceitos estéticos ultrapassados" que ainda reinavam na Áustria. Thomas Antonic (2018: 38) também põe em destaque a capacidade de renovação estética de Bauer, que teria sido capaz de "alargar os limites do teatro e chegar a uma originalidade extraordinária".

Outras vozes têm ressaltado o potencial dos microdramas de provocar o público comum ou, pelo menos, parte dele. Marlene Streeruwitz, escritora austríaca que dedicou sua tese de doutorado a uma análise dessas miniaturas dramáticas de Bauer, resume a história de sua publicação e recepção de modo marcante: um "episódio" de "terror da burguesia" [Bürgerschreck-Geschichte] (DISKUSSION 1999: 369). Numa entrevista de 1997, Elfriede Jelinek, que ganhou o Prêmio Nobel de Literatura em 2004, apresenta uma avaliação semelhante: "Em retrospectiva, a natureza anárquica da arte de um Wolfgang Bauer, por exemplo, me parece no mínimo tão política quanto aquela com a qual nós, na mesma época, tentamos contribuir em termos de teoria" (apud KORTE 1997: 275)9.

\footnotetext{
${ }^{8}$ Por exemplo, Hellmuth Karasek, em uma resenha no jornal Stuttgarter Nachrichten, em 18 de dezembro de 1964, ironizou a curta duração das peças observando que se a tendência de encurtar cada vez mais os dramas continuasse naquele ritmo, os espectadores poderiam deixar seus carros estacionados em lugares proibidos com o motor ligado enquanto durasse a sua apresentação (ANTONIC 2018: 104).

${ }^{9}$ Com esse "nós", Jelinek está se referindo a um grupo de artistas que incluía, além de si mesma, Wilhelm Zobl e Michael Scharang, que nos anos 1960 só escrevia textos de explícito engajamento político (KORTE 1997: 275). Jelinek parece expressar aqui uma guinada de sua própria avaliação do papel político de certas produções artísticas da época - enquanto, nos anos 1960, ela exigia a literatura engajada como via única e necessária para se obter algum impacto na sociedade, nos anos 1990 opina que a obra de Bauer, um autor que nunca mostrou a intenção de se associar a algum movimento político, podia também ter tal repercussão.
}

Pandaemonium, São Paulo, v. 24, n. 42, jan.-abr. 2021, p. 304-332 
Bohunovsky, R. - Os microdramas de Wolfgang Bauer

Resumindo: por um lado, o grande número de apresentações, mesmo fora do círculo de Graz, publicações isoladas de microdramas, gravações etc. apontam um vivo interesse e uma recepção positiva dessas pequenas peças na época em que foram escritas (ANTONIC 2011: 175-177). Por outro, a definição dos microdramas como "terror da burguesia", feita por Streeruwitz, indica que nem todos mostravam essa mesma reação.

O interesse central deste artigo é o possível efeito provocativo que o cômico pode ter. Os microdramas de Bauer parecem bastante adequados para esse debate. Neles, a comicidade revela-se com força e é facilmente perceptível, mesmo numa leitura (dramática) dos textos. Seu potencial provocativo também é evidente, como mostram alguns dos comentários citados até agora. Além disso - o que se torna relevante para uma discussão em âmbito brasileiro - suas temáticas não estão estritamente relacionadas a algum aspecto da cultura austríaca ou europeia cujo conhecimento seria necessário para se obter um efeito cômico. É importante ressaltar que não pretendemos apresentar uma proposta de interpretação exaustiva daquilo que os microdramas significam. Visto a sua proximidade com aquilo que costumamos chamar de absurdo ou nonsense, entendemos que qualquer tentativa de se chegar a uma interpretação precisa e inequívoca seria em vão, já que obras associáveis a essa vertente empregam justamente estratégias de diversos tipos para criar ambiguidades. Tentamos sim apresentar alguns complexos temáticos, estruturas formais e estratégias (dramáticas?) que permitam definir certas semelhanças entre os 21 pequenos textos.

À primeira vista, parece difícil entender por que os microdramas possam ter um efeito provocativo e/ou político, pois eles não contêm praticamente nada daquilo que costumamos associar com obras classificáveis como provocativas num sentido político ou moral: não contêm linguagem vulgar ou incitante (como o texto de Insulto ao público de Handke e algumas peças posteriores de Bauer) e não exigem cenas de nudez ou obscenas no palco (algo comum nas ações do Wiener Aktionismus [Acionismo Vienense $]^{10}$ da mesma época). A única cena de sexo que ocorre nesses textos está em Romeo und Julia [Romeo e Julieta] e se limita à seguinte indicação "Romeo e Julieta realizam um rápido ato sexual”; além do mais: "antes de os dois terminarem, cai o pano"11

\footnotetext{
${ }^{10}$ Grupo da vanguarda artística austríaca que atuou principalmente entre 1962 e 1970, chamando a atenção pública e política por ações agressivas, ferindo tabus e normas da sociedade. Algumas ações tiveram como resultado processos jurídicos.

${ }^{11}$ No original: "Romeo und Julia bieten einen zügigen Geschlechtsakt. [...] noch ehe die beiden fertig sind, fällt der Vorhang. "
} 
Bohunovsky, R. - Os microdramas de Wolfgans Bauer

(BAUER 1987: 211). Os microdramas não expressam nenhuma crítica explícita em relação a instituições, normas ou representantes legitimados pela sociedade burguesa e política dominante e não tratam de temas comumente avaliados como sensíveis para o "bom gosto" e o "senso comum” burguês dos anos 1960 (como opressão e/ou liberação política, igualdade de gênero ou mecanismos do poder patriarcal). Também não tocam no tabu da participação austríaca nos crimes da Segunda Guerra Mundial. O próprio autor (apud SCHMÖLZER 1973: 45) entende seus microdramas estritamente como experimentos formais com o objetivo de desapontar as expectativas do público em relação às convenções teatrais:

Eu faço peças que vivem, sobretudo, por causa da expectativa do público. O público está acostumado há séculos com certas coisas no teatro - e essas expectativas não são cumpridas [pela minha obra].

Interessa-nos argumentar que o potencial provocativo dos microdramas - que, ao mesmo tempo, pode ser percebido como libertador - não consiste somente na tendência de transgressão de certas convenções teatrais, como sugere esse último comentário do autor.

Contudo, antes de entrar nessa discussão, consideramos útil dedicar ainda algumas páginas a uma apresentação do autor e de sua obra, especialmente dos microdramas, levando em consideração que Bauer e sua obra são praticamente desconhecidos no Brasil.

\section{Wolfgang Bauer}

Wolfgang Bauer nasceu em Graz, na capital do estado austríaco da Estíria. Foi lá também que iniciou sua vida artística como representante de destaque do movimento literário da cidade, que, majoritariamente, encontrava-se associado ao Forum Stadtpark e à sua revista manuskripte - desde os anos 1960 instituições importantes na tentativa de se opor à literatura tradicional ainda vinculada ao ideário nazista de "sangue e solo" e/ou a formas literárias sentimentais enraizadas em ideias nacionalistas do século XIX. Outros nomes dessa primeira fase do Forum Stadtpark foram, por exemplo, Peter Handke e Barbara Frischmuth.

A importância de Wolfgang Bauer no cenário literário austríaco (e além dele) tem sido ressaltada por muitos autores. Elfriede Jelinek (2011:11) o chamou de o "maior dramaturgo" da Áustria e considera os microdramas os "melhores trabalhos" de Bauer 
Bohunovsky, R. - Os microdramas de Wolfgang Bauer

(apud KORTE 1997: 277). Em 1981, Gerhard Melzer (1981: 7) apontou três nomes como sendo "certamente" os "mais conhecidos autores da Áustria": Thomas Bernhard, Peter Handke e Wolfgang Bauer ${ }^{12}$. E, na segunda edição de sua obra clássica: O teatro do absurdo, Martin Esslin (2006) incluiu um pequeno capítulo em que menciona os mesmos três autores como os únicos representantes austríacos do teatro do absurdo ${ }^{13}$. Esslin traduziu e encenou diversas peças de Bauer em teatros nos EUA, sobretudo nos anos 1970 e 1980 (MosSE 2008), tornando-se assim responsável pela grande popularidade que esse autor alcançou naquele país. Esslin proferiu também um discurso em homenagem ao amigo quando este recebeu o Grande Prêmio do Estado da Áustria para Literatura em 1995. Quando Wolfgang Bauer faleceu, em 2005, diversos jornais de língua alemã citaram os comentários de Peter Handke de que Bauer teria sido "o gênio entre todos nós" e, “quando jovem, o único gênio da Áustria” (apud ANTONIC 2018: 11).

Parte das obras de Handke e Bernhard, dois dos três autores citados por Melzer como "os mais conhecidos da Áustria" nos anos 1980, tem sido traduzida, publicada e discutida no Brasil. Isso não vale para Wolfgang Bauer. Em solo brasileiro, temos apenas uma tradução da peça Change, publicada em 1978 no caderno número 9 da série "Teatro alemão" (BAUER 1978) e disponível somente em algumas bibliotecas do Instituto Goethe.

$\mathrm{Na}$ Áustria, Bauer passou por uma fase de intensa recepção e celebridade nas décadas 1970 e 1980, seguida por anos de uma presença mais reduzida e em parte questionada - atribuída por Jelinek à "hostilidade da pós-modernidade em relação à vanguarda" (KORTE 1997: 279). Em 2015, dez anos após a morte de Bauer, a versão integral de sua primeira peça de longa duração, Der Rüssel [A tromba], foi encontrada. Bauer escreveu essa obra na mesma época em que criou os microdramas, mas ela estava desaparecida desde então. A estreia de Der Rüssel no Akademietheater em 2018 somada a publicações e estudos recentes sobre o autor - por exemplo, os trabalhos reunidos no Dossier Wolfgang Bauer da Universidade de Graz (2017) e os diversos livros da autoria de Thomas Antonic (2011a; 2011b; 2018) - têm contribuído para uma renovação do

\footnotetext{
${ }^{12}$ Hoje, Elfriede Jelinek - que ganhou o Prêmio Nobel em 2004 - certamente seria mencionada como membro desse grupo seleto. Ao mesmo tempo, a escolha de Handke para o Prêmio Nobel de Literatura, em 2019, deve ter fortalecido ainda mais o seu nome.

${ }^{13}$ Esslin destaca a "total falta de ação" dos protagonistas de uma das peças mais famosas de Bauer, Magic Afternoon, como indício de uma proximidade entre o teatro de Bauer e o de Samuel Beckett: "Magic Afternoon' é em certa medida uma variação de 'Esperando Godot', só que próximo ao realismo extremo" (ESSLIN 2006: 345). Jelinek classifica os microdramas de Bauer como "teatro absurdo per se" (KORTE 1997: 277).
} 
Bohunovsky, R. - Os microdramas de Wolfgang Bauer

interesse pela obra de Bauer nos últimos anos. Em Viena, em 2019, além de Der Rüssel, ainda estavam em cartaz a peça Magic Afternoon (num palco secundário do Theater an der Josephstadt) e uma apresentação musical baseada no manifesto Happy Art \& Attitude de Bauer (Bauer to the people, no teatro TAG, Theater an der Gumpendorferstraß $e^{14}$ ), durante a qual três microdramas também foram apresentados (Ramses [Ramsés], Die drei Musketiere [Os três mosqueteiros] e Tchingis Khan [Genghis Khan]) $)^{15}$.

Bauer sempre foi uma pessoa polêmica ${ }^{16}$. Ora aclamado como escritor genial, heterodoxo e apelidado de Magic Bauer, ora reprovado como dramaturgo de peças banais, como já comentamos. A crítica literária Sigrid Löffler, já citada acima, argumentou que a presença mediática do autor se devia muito mais ao seu alto consumo de cerveja e à sua competência comunicativa e social-oportunista do que à qualidade literária de seus textos (ANTONIC 2018: 385). Como também aponta Antonic (2017: 12), a imagem pública de Bauer foi um fator que contribuiu para que a sua obra fosse, frequentemente, depreciada.

Ao longo de sua vida, Bauer produziu uma obra extensa que inclui sobretudo dramas, mas também poemas (BAUER 1992), um romance, Fieberkopf, parcialmente ambientado no Brasil (BAUER 1986), pequenos textos em prosa, ensaios e manifestos (BAUER 2011). Geralmente, a crítica divide sua produção literária em diversas fases. Antonic, por exemplo, propõe a seguinte divisão: uma fase inicial, marcada por forte influência do teatro do absurdo e pelo lançamento dos 21 microdramas. Depois, uma segunda fase, quando a influência da cultura beat e pop se intensificou. A produção dessa fase é caracterizada por diversas semelhanças formais e temáticas com artistas internacionais como Jack Kerouac e Andy Warhol (ANTONIC 2017: 7, 10). Em seguida, uma terceira fase em que Bauer teve seu tempo de maior sucesso, com peças consideradas "hiper-realistas" - os pontos altos dessa etapa foram, sem dúvida, Magic Afternoon, de 1968, e Change, de 1969. Na seguinte, a fase chamada de filosófica, Bauer se dedicou a experimentos mentais referentes ao sonho e à anulação das convenções relativas ao espaço e ao tempo (por exemplo, em Magnetküsse [Beijos magnéticos], de 1975). Por

\footnotetext{
${ }^{14} \mathrm{Cf}$. http://www.dastag.at/produktionen/bauertothepeople/.

${ }^{15}$ Essa apresentação musical parte do manifesto Happy Art \& Attitude, publicado em 1965 por Wolfgang Bauer e Peter Falk. Nesse texto, os dois autores propõem a "arte do prazer pela vida", "um movimento" que seria "o mais importante desde o cristianismo". Uma versão fac-símile pode ser vista na página do Literaturhaus Graz: http://www.literaturhaus-graz.at/wolfgang-bauer-gunter-falk-1-manifest-der-happyart-attitude-1965/.

${ }^{16}$ Sobre a construção e o papel da imagem pública de Wolfgang Bauer ao longo de toda sua vida artística, (cf. ANTONIC 2017).
}

Pandaemonium, São Paulo, v. 24, n. 42, jan.-abr. 2021, p. 304-332 
Bohunovsky, R. - Os microdramas de Wolfgang Bauer

fim, uma quinta fase, em que o interesse principal foram assuntos como a autorreflexão e a metaficção, por exemplo, em Café Tamagotchi (ANTONIC 2018) ${ }^{17}$. Com as peças das últimas duas fases, o sucesso foi menor, tanto entre o público quanto por parte da crítica.

\section{Os microdramas e seu potencial cômico}

O gênero do minidrama tem uma longa tradição. No livro Minidramen [Minidramas], de 1987, Karlheinz Braun reuniu 111 exemplos de autores diversos, tais como: Guillaume Appollinaire, Gertrude Stein, Urs Widmer, Harold Pinter, Kurt Schwitters, Thomas Bernhard, Karl Valentin, Dario Fo e Arthur Schopenhauer. Especificamente na tradição literário-teatral da Áustria, destacam-se o pequeno drama satírico Der wilde Jäger [O caçador selvagem], de Franz Grillparzer (2006: 28-29), os minidramas de Elfriede Jelinek (BRAUN 1987) e dos membros do Grupo de Viena (BUCHER 1992) ou os curtos diálogos teatrais reunidos em Der deutsche Mittagstisch [Almoço alemão], de Thomas Bernhard ${ }^{18}$, assim como os pequenos Dramulette de Antonio Fian, que vêm sendo publicados regularmente em jornais austríacos e em forma de livro ${ }^{19}$, para citar apenas alguns nomes de autores austríacos.

O nome microdrama foi criado pelo próprio Wolfgang Bauer (em colaboração com o editor Wolfgang Fietkau) para produzir um efeito de originalidade. Uma fonte de inspiração para esse termo pode ter sido o fragmento Hanswursts Hochzeit oder der Lauf der Welt [O casamento do João Linguiça ou O andar do mundo], de Johann Wolfgang von Goethe (1775), qualificado pelo seu autor como um "drama microcósmico" (ANTONIC 2018: 101). A peça de Goethe não possui ação e nem diálogos dramáticos, consiste apenas numa listagem de palavrões do vocabulário ligado à escatologia e à sexualidade pronunciadas por João Linguiça em ocasião de seu casamento, visto por ele como um estorvo para alcançar seu objetivo central: iniciar sua relação sexual com a noiva.

Conforme Antonic, o termo microdrama é hoje "componente fixo" da terminologia técnica dos estudos literários e usado para se referir especificamente às micropeças de Bauer. Trata-se de radicais reduções cênicas, geralmente são consideradas

\footnotetext{
17 Wilhelm Hengstler (2017: 90) defende que as peças da última fase produtiva de Bauer lembram em diversos aspectos os microdramas, escritos no início de sua carreira.

${ }^{18}$ BERnhard, Thomas. Der deutsche Mittagstisch. Berlin, Suhrkamp, 1999.

${ }^{19}$ Por exemplo: FIAN, Antonio. Schwimmunterricht, Dramolette VI, Wien, Graz, Droschl, 2016.

Pandaemonium, São Paulo, v. 24, n. 42, jan.-abr. 2021, p. 304-332
} 
Bohunovsky, R. - Os microdramas de Wolfgans Bauer

peças escritas apenas para serem lidas, não encenadas. São "metadramas" que levam ao absurdo o teatro convencional "em todos os níveis", "roubando" sua "aura", seja por redução, exagero ou banalização de ação e diálogo. Embora quase toda a obra dramática de Bauer tenha como um de seus temas centrais o próprio teatro, nos microdramas essa pretensão metateatral é realizada de forma mais radical, pagando o preço de se perder assim a possibilidade de levá-los ao palco (MELzER 1981: 43). No entanto, não é absolutamente impossível encenar os textos, como mostram algumas montagens feitas pelo Kabinetttheater de Viena, com atores reais e marionetes ${ }^{20}$. Levando em consideração o fato de que os microdramas não cumprem aquilo que geralmente é considerado um prérequisito de um drama (um conflito e a pretensão de uma apresentação cênica), o próprio fato de essas miniaturas textuais serem denominadas de "dramas" já aponta a sua dimensão subversiva - essa característica é comum, aliás, a outras obras pertencentes ao gênero do minidrama, como será destacado mais adiante.

A primeira publicação dos pequenos textos ocorreu em 1964. A partir dessa data e ao longo das décadas seguintes, os microdramas foram muitas vezes apresentados em formato de leituras públicas, como comprova a listagem de resenhas e comentários em jornais austríacos elaborada por Antonic (2011: 175-177).

Os microdramas de Wolfgang Bauer têm diversos tamanhos. O menor deles (Lukretia [Lucrécia]) é uma peça de um ato e apenas 36 palavras, enquanto o maior (Richard Wagner) é dividido em sete atos, ocupando pouco mais de três páginas no livro que reúne Einakter und frühe Dramen [Peças de um ato e primeiros dramas] (BAUER 1987).

Assim como a obra falada Publikumsbeschimpfung do jovem Handke (que estreou em 1966, dois anos após a publicação das minipeças de Bauer), o conjunto dos microdramas ilustra uma postura radical de rejeição em relação às tradições dramáticas estabelecidas, de contestação ao status quo. Além disso, percebe-se a clara tendência de uma desintegração semântica e linguística, tão característica do teatro do absurdo em geral (ESSLIN 2006: 64).

Os microdramas cumprem - e ao mesmo tempo transgridem - as convenções teatrais. Isso pode ser visto já nos títulos, aparentemente compatíveis com o que se espera do gênero. Com a única exceção de Die Schlacht an der Beresina [A batalha de Berezina],

${ }^{20}$ Cf. www.kabinetttheater.at e a dissertação de mestrado: STRANSKY, Luzie. "Gebildetes und Eingebildetes " - Minidramen am Kabinetttheater. Universidade de Viena, 2010.

Pandaemonium, São Paulo, v. 24, n. 42, jan.-abr. 2021, p. 304-332 
Bohunovsky, R. - Os microdramas de Wolfgang Bauer

todas as peças têm como título o nome de algum personagem mitológico, histórico ou artístico: Ramses [Ramsés], Haydn, Die drei Musketiere [Os três mosqueteiros], Richard Wagner, Luther [Lutero], Wilhelm Tell [Guilherme Tell], Columbus [Colombo], Sigmund Freud etc. São nomes associados a mitos antigos e modernos e, portanto, conhecidos pelo público. Esse pré-conhecimento, mesmo que superficial, é importante para o efeito cômico que os textos podem ter ao serem lidos ou ouvidos. São grandes nomes que, espontaneamente, criam certa expectativa em relação ao trato considerado adequado (geralmente trágico) num texto dramático - e Bauer não cumpre essa expectativa, pois reduz a ação dos supostos heróis a atividades banais, "roubando-lhes a fala, deixando apenas um barulho trivial de palavras de vez em quando" (JANDL 1965: 59). Quando há algum tipo de ação, ela é indicada nas rubricas, não pelas falas. Bauer parte das conotações que espera encontrar no seu público para chegar a alusões inusitadas, opondose à dicotomia entre a tradição erudita e aquilo "que os objetos dessa tradição erudita realmente se tornaram" (MELZER 1987: 45). No microdrama Martin Luther, o protagonista, que usou pregos para afixar suas 95 teses na igreja do castelo de Wittenberg, torna-se dono de uma pequena loja em cuja vitrine se vê um cartaz com a informação: "pregos de todo tipo". Lutero não apenas encerra o primeiro ato comendo com grande prazer diversos utensílios de ferro de sua loja, mas chega a fixar "uma tese na barriga" de uma "senhora jovem e bonita" "21 (BAUER 1987: 215). Também em Romeo und Julia, ocorre uma mistura incomum entre personagens de duas esferas culturais geralmente bem separadas, a erudita e a popular, pois o famoso casal de amantes encontra-se tanto com Paris e Helena, Hero e Leander e Rômulo e Remo quanto com os Beatles e os irmãos Max e Moritz (BAUER 1987: 210-211).

Os microdramas seguem a convenção de dividir um texto dramático entre o texto primário (as falas dos atores e das atrizes) e o texto secundário (as indicações cênicas). Porém, a hierarquia desses dois subgêneros é invertida, o texto secundário ocupa a extensão total de quase todas as peças. Além disso, as rubricas "praticamente não oferecem instruções para a constituição cênica de uma sequência de ação fictícia" (Melzer 1987: 44). Em vez disso, elas "tematizam" a si mesmo como sendo "parte tradicional do código estético secundário" (MELZER 1987: 44) e subvertem sua tradicional função central, a descrição daquilo que o público deve ver no palco. Muitas vezes, preveem cenários impossíveis de serem mostrados, em outros casos oferecem uma

\footnotetext{
${ }^{21}$ No original: "Geht auf die hübsche junge Dame zu, schlägt ihr eine These auf den Bauch, daß es klirrt". Pandaemonium, São Paulo, v. 24, n. 42, jan.-abr. 2021, p. 304-332
} 
Bohunovsky, R. - Os microdramas de Wolfgang Bauer

descrição detalhada de um cenário ou um personagem que devem, no entanto, ficar escondidos do público. Por exemplo, em Die Schlacht an der Beresina, o primeiro ato prevê uma "paisagem encantada" em que, de vez em quando, dos "galhos dos abetos", cai um pouco de neve. Fora do palco haveria "três canhões" e em cena no "lado esquerdo", um bosque cuja parte interior "o público não consegue ver"; dentro dele, estaria um "russo de baixa estatura (que se chama Fernando)" e que "toca uma corneta"22 (BAUER 1987: 204). Fernando, o "russo de baixa estatura" não aparece no palco ao longo de todo o microdrama, sua única "fala" acontece no segundo ato, "de longe, e rapidamente": “...Bo...” (BAUER 1987: 204).

Além de sua predominância em relação às falas dos personagens, as rubricas incluem instruções que vão além das possibilidades realistas. A primeira rubrica de Cassandra (BAUER 1987: 212) começa assim:

O palco é uma obra numa rodovia. Janeiro. Máquinas e trabalhadores de todo tipo estão em ação. No primeiro plano, é possível ver que o asfalto está com defeitos. Grandes buracos devido aos congelamentos. Temperatura no palco: $-31^{\circ}$. [...] em uma das barracas dos trabalhadores está sentada Cassandra, de olhos arregalados, conforme planejado $(\mathrm{O}$ público não vê dentro dessa barraca) ${ }^{23}$

Além da temperatura de $-31^{\circ}$, o mesmo microdrama ainda exige, no segundo ato, a presença no palco de 300 galinhas, que começariam a dançar charleston (BAUER 1987: 213). Die drei Musketiere inicia com um "prelúdio" que prevê um avião do tipo DC-6 no cenário, antes da entrada do público no teatro. O diretor do teatro "entra no palco, liga a hélice, entra e sai voando, com um sorriso escarnecedor nos lábios”. Depois “cai o pano. O público entra"24 (BAUER 1987: 201). No sétimo ato de Richard Wagner, estão previstos no cenário diversos animais como tartarugas, lobos e salmões, "10.000 apaches", além de "comanches, sioux, os técnicos do palco, o pessoal da bilheteria, o diretor da peça, o diretor do teatro, o autor (Bauer), o cenógrafo, a figurinista e o ponto", além de Hitler,

\footnotetext{
${ }^{22}$ No original: "Die Bühne zeigt eine auf das reizendste verschneite Landschaft. Tannenäste biegen sich glitzernd, werfen von Zeit zu Zeit jungen Pulverschnee von sich. Links ein Wald, rechts ein Ausblick auf die Beresina, die leise unterm Eis murmelt. Abseits drei Kanonen. Im Wald irgendwo (in den das Publikum nicht einsehen kann) steht ein kleiner Russe (genannt Ferdinand). Er bläst ein Waldhorn."

${ }^{23}$ No original: "Die Bühne ist eine Baustelle an einer Autobahn. Jänner. Maschinen und Arbeiter aller Art sind in Betrieb. Im Vordergrund sieht man, daß die Autobahn schadhaft ist. Arge Frostaufbrüche. Bühnentemperatur: -31 Grad. [...] In einer der flüchtigen Arbeiterhütten sitzt Cassandra mit planmäßig aufgerissenen Augen. (Das Publikum hat in diese Hütte nicht Einsicht)."

${ }^{24}$ No original: "Noch bevor man das Publikum in den Zuschauerraum gelassen hat, öffnet sich der Vorhang. Auf der Bühne steht eine DC-6. Der Intendant tritt auf, wirft den Propeller an, steigt ein und fliegt, ein süffisantes Lächeln auf den Lippen, davon."
} 
Bohunovsky, R. - Os microdramas de Wolfgang Bauer

“em pé"25 (Bauer 1987: 209). Em Ramses, as rubricas indicam "baleias voando pelo ar"26 (BAUER 1987: 198); e em Die Schlacht an der Beresina, após um breve aviso prévio no segundo ato ("Quem quiser, ainda pode sair" ${ }^{27}$ ), entra em cena Napoleão, alvejando o público com “armas pesadas” e canhões (BAUER 1987: 204)²8.

Embora os microdramas possuam falas de personagens, não há diálogos e nem ação. Algumas das rubricas avisam que a próxima cena não teria relevância no âmbito da peça e poderia (sobretudo em palco menores, devido aos altos custos de mudança de cenário) ser eliminada. Por exemplo, em Haydn, lemos o "comentário" de que o segundo ato não precisa ser apresentado, pois, "na verdade, não tem nenhuma relevância para o andamento do drama". Seu único objetivo seria satisfazer os "instintos primitivos do

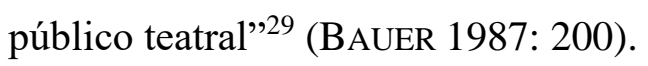

Como esperado de um drama, os microdramas preveem intervalos nas apresentações. Obviamente, não exatamente nos momentos e na medida esperada. Assim, Toulouse-Lautrec e Haydn preveem uma "ou duas" pausas já antes do primeiro ato (BAUER 1987: 199, 211), Herostratos uma “pausa escondida”, também antes do primeiro ato (BAUER 1987: 216). Em Richard Wagner, há um quarto ato "dedicado àquelas pessoas que acreditam que o mais importante de Wagner seriam suas óperas". Após essa dedicatória, a rubrica continua de modo coerente: “Agora, sem pausas e sem comentário, apresentam-se todas as óperas de Wagner". Depois dessa parte, cai o pano e, antes do quinto ato, o público pode se recompor numa "curta pausa para fumar um cigarro" 30 (BAUER 1987: 207).

Nas palavras de Volker Hage (1972: 16), os microdramas de Bauer apostam, por um lado, "no exagero que aponta para os limites do teatro" e, por outro, "na negação de dar ao teatro aquilo que é do teatro". Para entender que há incongruências (às vezes absurdas) e contradições não é necessário que o público conheça pormenores das

\footnotetext{
${ }^{25}$ No original: "Die 10000 Apachen, die Komanchen und die Sioux, die Bühnenarbeiter, Billetteusen, der Regisseur, der Intendant, der Autor (Bauer), der Bühnenbildner, die Kostümbildnerin und die Souffleuse. Stehend: Hitler."

${ }^{26}$ No original: "Walfische fliegen durch die Luft."

${ }^{27}$ No original: "Wer jetzt noch gehen will, kann gehen."

${ }^{28}$ Talvez uma referência à "ópera romântica" em formato de minidrama de Franz Grillparzer (2006).

${ }^{29}$ No original: "Der zweite Aufzug, für den Fortgang des Dramas eigentlich überhaupt bedeutungslos, mehr Illustration, mehr auf die primitiven Instinkte des Theaterpublikums ausgerichtet, darf auf kleineren Bühnen (wegen Umbauspesen) unaufgeführt bleiben."

${ }^{30}$ No original: "Der vierte Akt ist jenen Leuten gewidmet, welche der Ansicht sind, das Wichtigste an Wagner seien seine Opern. Man läßt nun pausenlos und ohne Kommentar sein gesamtes Opernwerk revuepassieren. Abschließend: Vorhang (kurze Zigarettenpause)".
}

Pandaemonium, São Paulo, v. 24, n. 42, jan.-abr. 2021, p. 304-332 
Bohunovsky, R. - Os microdramas de Wolfgang Bauer

biografias dos protagonistas ou das convenções teatrais, pois as transgressões dizem respeito a aspectos básicos da natureza de qualquer texto dramático e a aspectos da natureza e dos limites do ser humano e do mundo que compreendemos como real.

Incongruência é uma condição formal para qualquer manifestação do cômico (cf. MÜLLER-KAMPEL 2012: 13; MÜLLER 2013: 383) ${ }^{31}$. Nos microdramas, porém, faltam outros fatores que, em geral, estão associados com a comicidade: não há jogos de linguagem ${ }^{32}$, não há personagens cômicas nos moldes tradicionais (com foco numa corporeidade exagerada, na ingestão ou eliminação de alimentos e numa sexualidade descomedida), cujo efeito cômico se daria pela repetição de características associadas a certos tipos dramáticos e pela reação emocional por parte do público (como acontece, por exemplo, na figura afamada do João Linguiça [Hanswurst]. Também não há ação dramática cômica. No caso dos microdramas, trata-se de um cômico com forte viés intelectual, de uma aproximação espirituosa tanto acerca de convenções teatrais como acerca dos limites impostos pela realidade extrateatral. Os microdramas não possuem um punch-line como proposto pelo formato tradicional de uma piada ou um chiste. Podem ser entendidos como exemplos de um "cômico sem punch-line" [pointenlose Komik] (MÜLLER-KAMPEL 2012: 25), visando a abertura de um complexo de associações inusitadas e heterogêneas por parte dos leitores ou espectadores. Portanto, o leitor ou espectador está diante de um exemplo de comicidade não convencional que procura, acima de tudo, provocar um desconforto em relação a figuras firmemente estabelecidas no imaginário ocidental.

\section{$4 \bigcirc$ riso como liberação e provocação}

Na introdução de sua coletânea, Braun (1987: 9-11) apresenta algumas "frases acerca do minidrama", ressaltando que as obras desse gênero geralmente nem pretendem ser montadas. Portanto, “podem expressar muito bem com meios lúdicos o que não é possível

\footnotetext{
${ }^{31}$ Porém, é importante lembrar que a simples existência de uma incongruência não garante o efeito cômico. Esse se dá, como aponta, por exemplo, Cristina Larkin-Galiñanes (2017: 12), quando há também outros fatores, como desvios da norma linguística, exageros, surpresa, expectativas decepcionadas - todos fatores evidentes nos microdramas de Bauer.

${ }^{32}$ A única exceção é pouco engraçada e encontra-se em Richard Wagner: no quinto ato, um "cliente" pergunta pelo preço desse "Wagner ... äh .... äh". Após uma "pausa para o público rir", ele se corrige: "äh .... carro". No original: "EIN KUNDE (auf ein Auto deutend) Was kostet dieser Wagner ... äh ... äh (Lachpause fürs Publikum) ... äh ... Wagen."

Pandaemonium, São Paulo, v. 24, n. 42, jan.-abr. 2021, p. 304-332
} 
Bohunovsky, R. - Os microdramas de Wolfgang Bauer

representar no palco com meios cênicos" e permitem que o teatro ganhe "liberdade total" (BRAUN 1987, p. 10). Tal liberdade implica a eliminação da necessidade de se levar em conta a possibilidade de uma encenação dramática (Grillparzer [2006: 28-29], por exemplo, em O caçador selvagem, termina sua "ópera romântica" em formato de miniatura com a instrução de alvejar o público presente).

Minidramas são, portanto, uma forma ideal de "resistência contra a imposição tradicional, porém não questionada, de certas formas", contra um "sistema de regras inflexível" (Melzer 1981: 53). Melzer (1981: 53) definiu como "sentido" dos microdramas o fato de eles permitirem um "momento de liberdade que reacende[ria] a ordem estética que havia se tornado estéril, fazendo dos conteúdos [até então] presos nessa ordem algo novamente acessível à experiência”. Ampliando essa linha de argumentação, entendemos que a comicidade das pequenas peças pode intensificar esse movimento de liberação.

A relação entre cômico e liberação já foi observada por muitos autores, entre eles Mikhael Bakhtin e Charles Baudelaire. Para Bakhtin (2008: 142), o riso "carnavalesco", que relativiza tudo, destronando dogmas e hierarquias, resulta numa "alegre relatividade de qualquer regime ou ordem social, de qualquer poder e qualquer posição hierárquica". Essa sensação de relatividade, mesmo que momentânea e sem ameaçar de fato a validade da ordem estabelecida, implica uma compreensão carnavalesca do mundo, libertadora e renovadora. Baudelaire (1852 apud JAUSS 1976: 107), ao versar sobre o comique absolu (diferente do comique significatif, que é marcado por uma sensação de superioridade daquele que ri), destaca o caráter coletivo desse tipo de comicidade, que leva a um "triunfo sobre o medo, a coação e a repressão". De modo indireto, mas não menos claro, a possível relação entre cômico e liberação evidencia-se também nas muitas tentativas (históricas e contemporâneas) por parte de autoridades políticas e/ou morais de reprimir, proibir ou censurar o riso libertador ${ }^{33}$.

No seu estudo sobre "a vanguarda cômica de Wolfgang Bauer", Waggershauser (2016) parte da compreensão de Bakhtin sobre a cultura do riso na Idade Média para mostrar paralelos com o potencial cômico nos microdramas de Bauer. Argumenta que as peças unem a "experiência alegre-carnavalesca da ambivalência" com a "experiência dissonante do estranhamento" (WAGGERSHAUSER 2016: 79). Porém, enquanto as

\footnotetext{
${ }^{33}$ Cf., por exemplo, Müller-Kampel (2012).

Pandaemonium, São Paulo, v. 24, n. 42, jan.-abr. 2021, p. 304-332
} 
Bohunovsky, R. - Os microdramas de Wolfgang Bauer

reflexões de Bakhtin se concentram na inversão de hierarquias durante o período limitado do carnaval, os microdramas de Bauer seriam exemplos de textos que estimulam uma “cognição cômica” em nível individual e sem limites temporais (WAGGERSHAUSER 2016: 36). Como o riso carnavalesco discutido por Bakhtin, os microdramas de Bauer não reivindicam uma decisão entre uma ou outra ordem, salientando muito mais a "potencial falibilidade" de qualquer regra, "resultante da lógica de sua inversão" (WAGGERSHAUSER 2016: 80-81). A possibilidade do riso carnavalesco nesse sentido baseia-se, portanto, não numa proposta de uma ordem alternativa, mas na sensação de uma "falta de orientação transcendental” (WAGGERSHAUSER 2016: 81). Tal percepção não leva à negação de qualquer ordem, pois, “em oposição à experiência de totalidade, que é possível [...] num modo de compreensão séria, tais interpretações [cômicas] são marcadas pela ideia integrativa de unir aquilo que exclui com aquilo que é de fato excluído" (WAGGERSHAUSER 2016: 83). Ou seja, diferentemente de uma compreensão no modo sério, a compreensão cômica carnavalesca seria aberta para a sensação da ambivalência, sem que haja necessidade de eliminá-la.

Quando algo (uma situação, um texto, um comportamento etc.) não cumpre nossas expectativas, podemos reagir com reprovação. Nesse caso, não há nenhum ganho cognitivo, pois apenas afirma-se a validade da ordem que já conhecemos e que vemos ameaçada. Ou podemos reagir com o riso a um momento de incongruência. Tal riso evidencia, simultaneamente, a nossa compreensão da incoerência apresentada e o insight de que a ordem não cumprida é apenas uma entre outras possíveis ou uma tentativa de ordem num mundo desordenado. ${ }^{34}$

Uma das bases teóricas do estudo de Waggershauser (2016) sobre a "vanguarda cômica" de Wolfgang Bauer é o livro Diskursive Dummheit, de Uwe Wirth (1999). Sendo impossível apresentar aqui a extensa reflexão filosófica de Wirth, que vai muito além da nossa temática, consideramos útil resumir seu raciocínio acerca das possíveis reações do sujeito quando confrontado com uma experiência de ambivalência cômica. Segundo Wirth (1999: 339), em tal situação o sujeito interpretante pode assumir uma de duas

\footnotetext{
${ }^{34} \mathrm{~A}$ argumentação de Esslin, no seu estudo pioneiro sobre o teatro do absurdo, segue essa mesma direção, destacando o potencial libertador de peças associadas a essa vertente: "O reconhecimento de que todas as soluções e os conceitos tradicionais são enganadores e desprovidos de sentido não leva de jeito nenhum ao desespero; é, muito mais, o ponto de partida para uma nova maneira de consciência. Com tal compreensão, o homem ganha uma nova liberdade que o capacita de enfrentar os enigmas e horrores da existência humana com uma serenidade alegre" (ESSLIN 2006: 65).
} 
Bohunovsky, R. - Os microdramas de Wolfgang Bauer

posições: a primeira opção seria o papel do "juiz satírico", que visa à "condenação crítica do desvio cômico ou ignorante dos padrões do pensamento correto e da interpretação adequada". A segunda possibilidade seria assumir a posição de um "detective irônico" à procura de "incoerências cômicas", capaz de "entender [a comicidade] de modo autocrítico, porque algo - talvez até ele próprio - lhe pareça suspeito" (WIRTH 1999: 339). $\mathrm{Na}$ experiência do "juiz satírico", que parte da certeza de uma ordem estável de ideias, conceitos e normas e de uma "constituição necessária e de validade ampla e intersubjetiva da realidade" (WIRTH 1999: 338), o esforço interpretativo em relação a uma enunciação ou uma hipótese aparentemente absurda seria inútil e uma "perda" (WIRTH 1999: 334). A reação de Sigrid Löffler à obra de Wolfgang Bauer, associando-a à burrice e à ignorância, parece ter como base tal visão. Nesse caso chega-se, no máximo, a um riso sobre a obra e seu autor. A reação de alguém que assume a postura de um "juiz satírico" diante de uma experiência de incoerência (cômica ou absurda) seria a de chamar o enunciador "ao banco dos réus", condenando-o com base em uma "argumentação sensata" (WIRTH 1999: 339) e chamando a sua atenção para a irrelevância contextual e textual, para as contradições e os princípios lógico-pragmáticos desconsiderados. Para Wirth (1999: 339), tal postura pode ser associada ao "senso comum", que teria como uma de suas características a ausência de qualquer tipo de dúvida, "sobretudo de alguma dúvida em relação à linguagem" (WIRTH 1999: 340). Já a visão do "detective" seria capaz de alternar cognitivamente diversos paradigmas, níveis de atuação e papéis sociais (WIRTH 1999: 337). Seu olhar (e seu riso) acarreta uma "inversão carnavalesca" da "verdade dominante" do senso comum que, no entanto, não perde necessariamente sua validade, pois a "verdade dominante" é apenas invertida e pode, depois, voltar a seu estatuto anterior (WIRTH 1999: 341). O riso do "detective irônico" é um riso com um texto, uma peça, seus protagonistas e, em última instância, com o mundo como ele é, sempre beirando o absurdo. Esse riso tem como gatilho algo muito além do objeto tematizado pelo texto cômico - no caso dos microdramas, os temas ou figuras apresentadas. Ainda segundo Wirth, ao descobrir as incongruências, o "detective irônico" reage com a ativação de um modo cognitivo diferente do modo "sério" (que, no máximo, permitiria a classificação dos microdramas como nonsense). Ele é capaz de ganhar consciência sobre a " "ignorância estrutural' supraindividual do tecido da língua e da lógica" que, "ao mesmo tempo, potencializa e proíbe a possibilidade da autocontradição" (WAGGERSHAUSER 2016: 85). 
Bohunovsky, R. - Os microdramas de Wolfgang Bauer

O estudo de Waggershauser sobre a obra de Wolfgang Bauer corrobora tal interpretação, ao argumentar que a compreensão cômica alcançaria uma dimensão que uma compreensão séria não teria como atingir (WAGGERSHAUSER 2016: 15). Beatrix Müller-Kampel, num estudo detalhado sobre as mais diversas teorias do cômico, também versa sobre os contextos cognitivo-psicológicos do cômico. A estudiosa destaca a sensação momentânea de "alívio e liberação" (MÜLLER-KAMPEL 2012: 25 ) 35 causada pelo cômico, devido a uma "mais-valia semântica", um "sentido não esperado" (MüLLERKAMPEL 2012: 27).

Aqueles que Wirth chama de juízes satíricos são denominados por Müller-Kampel (2012) de “censores deste mundo". Trata-se daqueles que confundem o "sentido moral da burguesia que constitui o público teatral" com "a norma e o objetivo de uma poética" e que evidenciam uma forte tendência de enxergar o prazer causado pelo cômico não como uma "válvula" de algo geralmente não visível, mas como "causa e motor da rebelião" (MÜLLER-KAMPEL 2012: 25). Como exemplos da postura desses censores no âmbito da literatura de língua alemã, a teórica refere-se ao escritor, crítico e dramaturgo alemão Johann Christoph Gottsched (1700-1766) e ao escritor e político austríaco Joseph von Sonnenfels (1732-1817), duas figuras proeminentes na luta contra o personagem teatral João Linguiça [Hanswurst] e sua jocosidade corporal, no final do século XVIII. Embora a comicidade dos microdramas seja diferente daquela de figuras cômicas como o João Linguiça, a reação dos que se veem na posição de um juiz ou um censor possui semelhanças ao longo de diversas épocas e contribui para se entender o potencial provocativo de uma comicidade aparentemente absurda e sem alvo, como a dos microdramas. O que une os juízes satíricos, independentemente de seu poder efetivo de interferir na divulgação de certas obras, é a interpretação de certas manifestações do cômico como uma ameaça àquilo que entendem ser o bem geral do teatro, do homem, da sociedade. Explica-se assim por que, em épocas em que os detentores do poder político assumem essa posição - leia-se: em épocas em que o poder político se coloca na posição de poder e dever definir o valor artístico da produção cultural de um país -, temos tentativas (com ou sem sucesso) de censurar ou desacreditar certas manifestações

\footnotetext{
${ }^{35} \mathrm{Na}$ sua discussão sobre os contextos psicológicos do cômico e a relação entre cômico e inconsciente, Müller-Kampel baseia-se no estudo Der Witz und seine Beziehung zum Unbewussten, de Sigmund Freud (2009). Embora certamente interessante no contexto do presente artigo, não tratamos aqui da teoria de Freud.
}

Pandaemonium, São Paulo, v. 24, n. 42, jan.-abr. 2021, p. 304-332 
Bohunovsky, R. - Os microdramas de Wolfgang Bauer

artísticas, mesmo se elas não expõem nenhum engajamento político-crítico explícito. Obviamente, a Áustria dos anos 1960 não é o único exemplo de tal situação.

Outro estudioso que desenvolveu um modelo teórico útil para se entender o potencial provocativo da comicidade de um Wolfgang Bauer foi o sociólogo e teólogo americano Peter L. Berger. No seu livro Erlösendes Lachen [O riso redentor], de 1998, foca o elemento psicológico-cognitivo implícito e peculiar da compreensão cômica e trata, além disso, dos fatores sociais do riso em suas diversas manifestações. O sociólogo divide a experiência cômica em quatro "formas de expressão" (1998: 115): o riso como diversão, como consolo, como arma (no caso da sátira) e o riso como "jogo mental" [Jeux d'Esprit]. Desses quatro tipos, parece ser o último que vem à tona em parte do público de Bauer. Diferentemente da sátira, que seria o uso da comicidade para um ataque militante a partir de uma posição de suposta superioridade moral e contra um alvo bem definido [BERGER 1998: 185-186], a comicidade do "jogo mental" seria "mais pura" e teria o efeito cognitivo de providenciar um momento de insight sobre as ambiguidades da realidade sem, no entanto, partir da pretensão de alguma superioridade daquele que ri sobre o objeto do seu riso. Nessa forma, o cômico não persegue um interesse específico, não possui um alvo concreto. Enquanto a sátira usa o cômico como "arma" contra algo ou alguém, o cômico do "jogo mental” tem a função de um "brinquedo" (BERGER 1998: 160) capaz de suscitar uma “intenção cognitiva” (BERGER 1998: 161), uma nova compreensão.

Berger (1998: 43) procura entender o que seria "exatamente "compreendido"” numa experiência cômica. Chega a uma resposta que transcende os limites de determinadas facetas da vida. A seu ver, "a experiência da contradição entre ordem e desordem", na qual se baseia a experiência cômica dos "jogos mentais", revela nada menos que "a verdade determinante da existência humana", a condição do homem de estar "numa situação da contradição cômica em relação à desordem do universo" (BERGER 1998: 43). Ou seja, a experiência cômica ofereceria um "diagnóstico" especial do mundo, a comicidade "olha através das fachadas da ordem ideológica e social e revela outras verdades que lá esperam" (BERGER 1998: 44). Trata-se de uma certa visão de mundo a partir da qual o riso não seria limitado temporalmente (como o riso carnavalesco de Bakhtin), mas ligado a um estado cognitivo potencialmente interminável (ou, pelo menos, acessível a qualquer momento pelo sujeito que ri). Desse modo, segundo Berger (1998: XI), a experiência do cômico na forma do "jogo mental” pode anular os limites da 
Bohunovsky, R. - Os microdramas de Wolfgang Bauer

existência humana, incluindo até uma "promessa de redenção", aproximando-se assim da experiência religiosa ${ }^{36}$.

Berger (1998: 162) também destaca que textos cômicos podem, "muitas vezes, resumir uma situação complexa de modo extremamente preciso e reduzido. Eles simplificam e esclarecem algo e possuem, sem dúvida, a capacidade de provocar uma nova compreensão". Isso pode ocorrer em piadas, aforismos e comédias. Os microdramas seriam, sem dúvida, outro exemplo. Qualquer forma desse cômico "puro", intelectual, teria duas características: em primeiro lugar, uma posição distanciada, até cética e de outsider, em relação ao objeto do riso (BERGER 1998: 166). O olhar promovido pelos microdramas acerca do teatro é, certamente, esse olhar de fora, de alguém que não segue aquilo que é considerado sagrado e inquestionável para a elaboração de um drama. A segunda característica seria para Berger uma ausência da "paixão moralizante" (típica da sátira, que visa a difamação de algo ou alguém a partir de um ponto de vista supostamente superior). No caso do "jogo mental”, a falta de uma argumentação moral contribui para a sua frequente identificação com o cômico intelectualizado, "mental", que não promove uma determinada visão de mundo como melhor que outra, como "niilismo moral" (BERGER 1998: 166). Esse foi justamente o atributo muitas vezes usado pela crítica para se referir a Bauer. Hengstler (2017: 93) aponta que, até hoje, Bauer é acusado de defender um "cinismo apolítico".

Sem atribuir ao cômico uma posição superior em termos de moralidade, e sem negar que o cômico possa ser usado também para "fins moralmente condenáveis", Berger (1998: 182) frisa que o cômico é "perigoso e tendencialmente subversivo", pois contribui para revelar as contradições e ambiguidades do mundo, suas "múltiplas realidades, sua dicotomia de fachada e de segundo plano", assim como a "fragilidade daquilo que nos aparece como realidade".

Podemos resumir que a experiência cômica do jogo mental faz mais que trazer um novo olhar sobre o objeto ao qual se refere - no caso dos microdramas, os personagens centrais e as convenções teatrais. Seu potencial revelador e de ceticismo transcende também o âmbito sociológico, pois adentra a esfera metafísica: “A sociedade não é o que parece ser. O mundo todo não é o que parece ser" (BERGER 1998: 182). De modo

\footnotetext{
${ }^{36}$ Para sua defesa de uma proximidade entre a experiência do cômico e a do religioso, Berger baseia-se, entre outros autores, nas ideias filosóficas de Pascal e Kierkegaard, que viram no cômico "algo como uma entrada para a fé religiosa" (BERGER 1998: 35).
}

Pandaemonium, São Paulo, v. 24, n. 42, jan.-abr. 2021, p. 304-332 
Bohunovsky, R. - Os microdramas de Wolfgang Bauer

semelhante, a grande filósofa húngara Ágnes Heller (2018: 133) afirma que o olhar da comicidade irônica e humorística ultrapassa a natureza de uma ferramenta retórica, pois adentra as "esferas existenciais", constituindo uma "postura do sujeito, o olhar do indivíduo dirigido ao mundo, tanto ao mundo imanente quanto ao mundo transcendental" (HELlER 2018: 133). Essa afirmação de Heller refere-se àquilo que ela chama de “comédia existencial", ou seja, o "teatro do absurdo" (HELLER 2018: 124-159), vertente na qual a obra de Wolfgang Bauer costuma ser incluída. A partir de tal perspectiva cômica, o mundo não corresponde à ordem racional, ele é caótico e absurdo; a ordem que costumamos entender como "natural" passa a ser relativa: "O mundo deixa de ser $o$ mundo, ele é apenas um mundo e, ainda por cima, um mundo ridículo" (BERGER 1998: 181).

Voltemos a Wolfgang Bauer e seus microdramas. À luz das reflexões apresentadas, permitem-se algumas aproximações interpretativas. No microdrama Franz Xaver Gabelsberger - Erfinder der Schnellschrift [Franz Xaver Gabelsberger - inventor da estenografia], o protagonista se joga numa piscina cheia de um líquido vermelho e viscoso, em cuja superfície sobrenada uma grande quantidade de macarrão fino. Com o impacto do pulo de Franz Xaver, um quadro branco posicionado do lado é atingido. "O macarrão e o vermelho respingam no quadro e, mesmo tremendo, os fios da massa se fixam lá (em forma de pontos, curvas e linhas) (BAUER 1987: 198) (77 $^{37}$ constituindo assim o início de um novo sistema de escrita. Nessa cena, não estamos diante de uma crítica pontual ou uma sátira sobre algum aspecto da estenografia ou seu processo de invenção. Com sua visão cômica acerca desse momento de criação de um sistema simbólico, Bauer aponta para a arbitrariedade de qualquer sistema simbólico, ou seja, trata, no fundo, de um assunto de relevância sem limites temporais ou espaciais. Um pequeno episódio ficcional, inspirado num acontecimento histórico e regionalmente demarcado, torna-se assim o gatilho para criar uma miniatura textual sobre uma temática perene e global e cuja poética antirrealista, fantástica, cômica e subversiva pode ser apreendida por qualquer público. A ativação do potencial liberador ou provocativo não se limita ao contexto de um público que tenha certos conhecimentos prévios linguísticos e/ou culturais - muitas vezes considerados necessários para se poder compreender a comicidade de um texto - mas pode ocorrer em qualquer ambiente, em qualquer país, em

\footnotetext{
${ }^{37}$ No original: "Nudeln und Farbe spritzen auf die Tafel, bleiben dort (als Punkte, Krümmungen und Linien) zitternd kleben."

Pandaemonium, São Paulo, v. 24, n. 42, jan.-abr. 2021, p. 304-332
} 
Bohunovsky, R. - Os microdramas de Wolfgang Bauer

qualquer língua. Desse modo, os microdramas podem ser considerados pequenas provocações dramáticas de grande valor poético-literário que merecem recepção e tradução em nível internacional - incluindo o Brasil, sobretudo num momento histórico com fortes tendências políticas e discursivas que procuram estabelecer "verdades" supostamente inabaláveis. Em última instância, isso significa que no atual cenário brasileiro os microdramas talvez possam - mais do que na própria Áustria atual - cumprir seu potencial liberador e/ou provocativo de modo semelhante como o fizeram no contexto de sua primeira publicação e de seu primeiro contato com o público de língua alemã.

Algo semelhante pode ser observado em Ramses, quando a rubrica exige "um templo em chamas (incêndio total de um templo)"38 (BAUER 1987: 198). O que está em questão aqui não são apenas os limites da realidade material e espacial - um assunto cuja relevância se limitaria, muito provavelmente, a profissionais e estudiosos do teatro. Esse microdrama trata, sobretudo, dos limites daquilo que entendemos como normalidade ou realidade num sentido genérico tornando-se assim uma pequena peça sobre um assunto que diz respeito ao ser humano em geral, ao seu lugar no mundo, sua relação com o mundo e, inclusive, sua posição política, pois entender o caráter relativo de qualquer "realidade" e qualquer "verdade" é pré-requisito primordial para uma postura democrática e tolerante. Como vimos na argumentação apresentada acima, o riso pode ser uma peça-chave nesse jogo de relações.

Em Richard Wagner, o protagonista não pode aparecer no quinto ato por estar “em Hong Kong, de onde não pode sair devido a um encontro urgente (com o marido da percussionista do segundo ato)" ${ }^{\prime 39}$ (BAUER 1987: 208). Aqui também não se trata de uma sátira ou uma paródia do famoso compositor alemão (algo certamente pouco relevante ao se pensar sobre o contexto de recepção brasileiro), nem das convenções teatrais (novamente, um assunto de interesse para um público restrito), mas de um convite para explorar tudo que está atrás daquilo que entendemos como posto, definitivo e inabalável - no caso da peça, a premissa de que os seus personagens não tenham família, vida própria e compromissos urgentes que possam impedir sua presença no palco. Na hipótese de se estender o convite para uma reflexão sobre o mundo fora do texto, abre-se um caminho

\footnotetext{
${ }^{38}$ No original: "Ein brennender Tempel (totaler Tempelbrand)."

${ }^{39}$ No original: "Wagner ist in Hongkong, dort hält ihn eine dringende Verabredung (mit dem Gatten der Schlagwerkerin aus dem zweiten Akt) fest, so daß es ihm bis zum Ende des fünften Aktes nicht möglich sein wird, auf die Bühne zu kommen.”
}

Pandaemonium, São Paulo, v. 24, n. 42, jan.-abr. 2021, p. 304-332 
Bohunovsky, R. - Os microdramas de Wolfgang Bauer

para um olhar menos dogmático, menos convicto, menos essencialista em relação a nossas próprias convenções.

No fundo, nesses três exemplos, o que se coloca em questão é a mesma coisa: o caráter, supostamente absoluto, das normas que regem nossas vidas, nossa língua, nossa escrita, nossa ideia daquilo que é e o que pode ser o teatro. É com o riso que entendemos o caráter relativo daquilo que, no dia a dia, precisa ser entendido como perene para que o convívio em sociedade possa funcionar. $\mathrm{O}$ riso nos liberta, pelo menos por um momento, da ideia do definitivo e do imutável. Assim, fica claro que a proposta política dos microdramas está intrinsecamente ligada à sua dimensão cômica que, por sua vez, não pode ser desvinculada do valor poético-literário dos textos bauerianos. Considerando todos esses fatores e sua interdependência mútua, é tanto pelo valor estético dessas miniaturas quanto por suas implicações políticas que se justifica o debate acadêmico, mas também sua divulgação entre um público maior em âmbito brasileiro. É objetivo do presente trabalho contribuir para essa empreitada.

\section{Conclusão}

Na Áustria, os anos 1960 estavam marcados por embates entre defensores de discursos tradicionais e diversos grupos e associações de artistas, parecia haver um abismo entre duas partes da sociedade e o diálogo entre elas aparentava ser impossível - um contexto histórico em que é possível ver certos paralelos com a situação da sociedade brasileira atual. Na Áustria da época, os tradicionalistas ainda estavam enraizados no pensamento nazista, nacionalista e na crença em valores e normas perenes, enquanto o grupo de oposição assumia, de modo cada vez mais explícito, posições contrárias ao status quo. Havia diversas maneiras de se opor ao ideário dominante, desde a publicação de cartas e textos de teor argumentativo-teórico (estratégia usada, por exemplo, por Elfriede Jelinek e alguns de seus colegas literatos) até ações de enorme poder provocativo, como aquelas promovidas pelo grupo do Acionismo Vienense. Wolfgang Bauer optou pelo riso, por uma "suposta posição niilista", em que "o maior sofrimento do mundo ganha um sentido alegre", como ele escreveu numa carta a si mesmo (ANTONIC 2017: 4). O que pode parecer uma mera banalização da realidade possui, como vimos, um potencial cognitivo, político-subversivo e provocativo. Segundo Daniela Bartens (2017: s.p.), o "reverso" do 
Bohunovsky, R. - Os microdramas de Wolfgang Bauer

"achatamento alegre" da realidade banalizada resulta até numa conscientização ainda maior de "todos os horrores" do mundo em que vivemos.

Ao se abster de temas políticos num sentido mais explícito e cotidiano, Bauer conseguiu dirigir o olhar para questões que tratam daquilo que há atrás das aparências e dos fenômenos políticos visíveis no nosso dia a dia. E é esse olhar que torna as peças de Bauer - não apenas os microdramas, mas praticamente toda sua obra - ainda interessante e relevante para o público atual. Podemos arriscar até uma estimativa de maior alcance. Em contextos politicamente radicalizados como o Brasil atual (mas certamente não apenas aqui), obras com as características cômicas e subversivas dos microdramas de Wolfgang Bauer, que se encontram no limiar entre o banal sobre o qual se pode rir e o complexo que provoca um riso universal (e que inclui aquele que ri), podem cumprir uma função provocativa semelhante àquela que cumpriam em seu contexto de origem. Sua dimensão política depende do contexto no qual são recebidos. Porém, sua relevância não se limita ao potencial provocativo, subversivo e político. Como procurei argumentar e ilustrar ao longo do texto acima, os microdramas possuem um alto valor inovador e poético que não apenas justifica, mas requer uma recepção em contextos linguísticos alheios ao do idioma alemão, seja em forma de publicação de traduções, seja em forma de leituras públicas. Em outras palavras, dependendo do contexto de recepção, os microdramas podem ou não ter impacto provocativo. Independentemente disso, possuem uma qualidade poético-literária que não perdeu sua força ao longo das décadas que passaram desde sua primeira publicação. Tal avaliação pode ser corroborada não apenas pelas atuais encenações de obras de Bauer em palcos austríacos, mas também pela intensa discussão acadêmica que sua obra ainda desperta nos dias de hoje. Nesse sentido, num artigo de 2017 sobre a obra de Wolfgang Bauer, Monika Meister (2017: 100) argumenta que "a ambivalência de realidade e ficção, de pensar e ser" na obra de Bauer mantém suas peças ainda "familiares" para o público contemporâneo. Sua "tensão [dramática] continua a funcionar", mesmo muito depois "do gesto de 1968 de um antiteatro, em parte porque somos céticos e porque sabemos das múltiplas e complexas realidades".

A renovação estética que Bauer defendia com seus microdramas não era l'art pour l'art, mas pretendia, "partindo da experiência da contínua presença escandalosa do pensamento nazista e da presença dos valores clerical-conservadores na Graz daqueles anos, uma mudança dessa situação através da transgressão estética” (BARTENS 2017: s.p.). Em vez de elaborar uma argumentação coerente acerca de tradições dramáticas e 
Bohunovsky, R. - Os microdramas de Wolfgang Bauer

tradições narrativas, Bauer apresentou peças que fugiram dessa lógica em diversos níveis (formais e temático-discursivos). Desse modo, podemos entender os microdramas de Bauer como um exemplo literário de um olhar cômico não apenas sobre as convenções dramáticas legitimadas, mas acerca de qualquer tipo de regra ou ordem humana.

Conforme apontado acima, a comicidade dos microdramas pode levar àquilo que Peter L. Berger define como "riso redentor", ligado a uma saída (temporária) da lógica da realidade dominante. Bauer não se interessa por definição alguma daquilo que seria "verdadeiro" ou "falso", mas pelo fato de qualquer sistema de conceitos ser nada mais que uma construção. Com essa dimensão cognitiva, o riso pode revelar aspectos da realidade que não são acessíveis para aquele que se aproxima de modo "sério" em relação a um determinado objeto. Sem querer assumir a premissa absoluta de que haja uma suposta superioridade de uma visão cômica acerca do mundo em relação a um olhar sério, fechamos nossas reflexões com a argumentação de Streeruwitz: "Dramas bem pequenos podem transportar tantas informações que, se fossem formuladas em prosa, requereriam uma quantidade enorme de texto" (DISKUSSION 1999: 370). Resumindo, este artigo pode ser entendido como uma tentativa de informar de um modo sério sobre algo que os microdramas informariam com muito menos texto e de um modo bem mais eficiente e melhor ainda - divertido.

\section{Referências bibliográficas}

Antonic, Thomas (org.). Wolfgang Bauer - Der Geist von San Francisco, Verstreut publizierte und nachgelassene Texte. Klagenfurt, Graz, Wien, Ritter, 2011a.

ANTONIC, Thomas. Wolfgang Bauer: Mediographie 1961-2011: Bibliographie, Szenographie, Audiographie, Filmographie. Wien, Praesens, 2011b.

ANTONIC, Thomas. Wolfgang Bauer: Werk, Leben, Nachlass, Wirkung. Klagenfurt e Graz, Ritter, 2018.

ANTONIC, Thomas. Wolfi Bauer ist tot, es lebe Wolfgang Bauer! Werk versus Image - oder Image als Teil des Werks. In: DossIER WOLFGANG BAUER. Organizado por Gerhard Fuchs e Stefan Maurer. Dossieronline. 2017. http://gams.uni-graz.at/o:lg.dossier.11 $(15 / 11 / 2019)$.

ATTARDO, Salvatore (org.). The Routledge Handbook of language and humor. New York, N.Y.: Routledge, 2017.

Bakhtin, Michail. Problemas da poética de Dostoiévski. 4. ed. Trad. Paulo Bezerra. Rio de Janeiro, Forense Universitária, 2008.

BARTENS, Daniela. Wolfgang Bauer / Gunter Falk: 1. Manifest der HAPPY ART \& ATTITUDE (1965). Literaturhaus Graz, 2017. http://www.literaturhaus-graz.at/wolfgang-bauergunter-falk-1-manifest-der-happy-art-attitude-1965/ (15/11/2019).

Pandaemonium, São Paulo, v. 24, n. 42, jan.-abr. 2021, p. 304-332 
Bohunovsky, R. - Os microdramas de Wolfgang Bauer

BARTSCH, Kurt. Wolfgang Bauer. In: DOSSIER WOLFGANG BAUER. Organizado por Gerhard Fuchs e Stefan Maurer. Dossier online. 2017. http://gams.uni-graz.at/o:lg.dossier.6 $(15 / 11 / 2019)$.

BAUER, Wolfgang. Change [Change]. Tradução ICBE Porto Alegre. Porto Alegre, Instituto Goethe, 1978.

BAUER, Wolfgang. Einakter und frühe Dramen. Werke Band 1. Graz, Wien, Droschl, 1987.

BAUER, Wolfgang. Fieberkopf. Ein Roman in Briefen. Werke Band 4. Graz, Wien: Droschl, 1986.

BAUER, Wolfgang, Gedichte. Werke Band 5. Graz, Wien, Droschl, 1992.

BAUER, Wolfgang. Der Geist von San Francisco - verstreut publizierte und nachgelassene Texte. Organizado por Thomas Antonic. Klagenfurt, Graz, Wien, Ritter Verlag, 2011.

BERGER, Peter L. Erlösendes Lachen. Das Komische in der menschlichen Erfahrung. Tradução para o alemão de Joachim Kalka. Berlin, New York, De Gruyter, 1998.

BRAUn, Karlheinz (org.). Minidramen. Frankfurt am Main, Verlag der Autoren, 1987.

BuCHER, André. Die szenischen Texte der Wiener Gruppe. Zürcher Germanistische Studien. Bern, Peter Lang, 1992.

DiSKUSSION MIT MARLENE STREERUWITZ, WOLFGANG BAUER, WOLFGANG REITER. In: RIGLER, Christine; ZEYRINGER, Klaus (org). Kunst und Überschreitung: vier Jahrzehnte Interdisziplinarität im Forum Stadtpark. Innsbruck, Wien, Studienverlag, 1999, p. 368387.

Dossier Wolfgang BAUER. Organizado por Gerhard Fuchs e Stefan Maurer. Dossieronline. 2017. Disponível em: http://www.literaturhaus-graz.at/inhalt/ (15/11/2019).

ESSLIN, Martin. Das Theater des Absurden: Von Beckett bis Pinter. Nova edição. Trad. Marianne Falk. Reinbek bei Hamburg, Rowohlt, 2006.

FIAN, Antonio. Schwimmunterricht: Dramolette VI. Graz: Droschl, 2016.

FREUD, Sigmund. Der Witz und seine Beziehung zum Unbewussten. Frankfurt: Fischer, 2009.

GOLLNER, Helmut; ZEYRINGER, Klaus. Áustria: uma história literária - literatura, cultura e sociedade desde 1650. Trad. Adapt. Ruth Bohunovsky. Curitiba: UFPR, 2019.

GRILLPARZER, Franz. Der Zauberflöte zweiter Teil und andere Satiren. Organizado por Dieter Holzinger. Berndorf, Kral, 2006.

HANDKE, Peter. Peças faladas. Trad. Org. Samir Signeu. São Paulo, Perspectiva, 2015.

HELLER, Ágnes. Was ist komisch? Kunst, Literatur, Leben und die unsterbliche Komödie. Wien, Hamburg, Konturen, 2018.

HENGSTLER, Wilhelm. Der Konstruktionskünstler. DOSSIER WOLFANG BAUER. Organizado por Gerhard Fuchs e Stefan Maurer. Dossier online. 2017. http://gams.unigraz.at/o:lg.dossier.11 (15/11/2019).

JANDL, Ernst. Wolfgang Bauer: microdramen (resenha). Wort in der Zeit, ano 11, caderno 3, 1965, p. 58-59.

JAUSS, Hans Robert. Über den Grund des Vergnügens am komischen Helden. In: PREISENDANZ, Wolfgang; WARNING, Rainer. Das Komische. München, Wilhelm Fink, 1976, p. 103132.

JELINEK, Elfriede. Ausgeronnen (2005). In: ANTONIC, Thomas (org.). Wolfgang Bauer - Der Geist von San Francisco, Verstreut publizierte und nachgelassene Texte. Klagenfurt, Graz, Wien, Ritter, 2011, p. 9-11.

KorTE, Ralf B. Gespräch mit Elfriede Jelinek. In: BARTEns, Daniela; PeChMAnN, Paul (org.). Elfriede Jelinek - Die internationale Rezeption. Wien, Droschl, 1997, 273-299.

LARKIN-GALIÑANES, Cristina. An Overview of Humor Theory. In: ATTARDO, Salvatore (org.). The Routledge Handbook of language and humor. New York, N.Y., Routledge, 2017, p. 4-17. 
Bohunovsky, R. - Os microdramas de Wolfgang Bauer

MEISTER, Monika. Dramaturgen der Zeit. Horváth, Bauer, Schwab. DosSIER WOLFGANG BAUER. Organizado por Gerhard Fuchs e Stefan Maurer. Dossieronline. 2017. http://gams.unigraz.at/o:lg.dossier.11 (15/11/2019).

MELZER, Gerhard. I bin ja auch net $>$ echt $<$ ' Absurde Wirklichkeitserfahrung im Werk Wolfgang Bauers. In: ARNOLD, Heinz Ludwig. Wolfgang Bauer. Text \& Kritik, caderno 59, München, text \& kritik, 1978, p. 16-23.

MELzER, Gerhard. Wolfang Bauer - Eine Einführung in das Gesamtwerk. Königstein/Ts., Athenäum, 1981.

Mosse, Ramona Franziska. Born to be wild - Zur Rezeption von Wolfgang Bauers Stücken in den USA. In: PechmanN, Paul (org.). Wolfgang Bauer - Lektüren und Dokumente. Klagenfurt, Ritter, 2008, p. 137-145.

MÜLlER, Beate. Komik und Komiktheorien. In: MetZler Literatur LEXIKON. Ansätze Personen - Grundbegriffe. Organizado por Ansgar Nünning. Stuttgart, Weimar, Metzler, 2013: 383-384.

MÜlleR-KAMPEL, Beatrix. Komik und das Komische: Kriterien und Kategorien. LiTheS, Zeitschrift für Literatur- und Theatersoziologie, n. 7, 2012, p. 5-39.

NichOLS, Bert. Die politische Heimat des Wolfi Bauer. In: ARNOLD, Heinz Ludwig. Wolfgang Bauer. Text \& Kritik, caderno 59, München, text \& kritik, 1978, p. 29-34.

Pechmann, Paul (org.). Wolfgang Bauer - Lektüren und Dokumente. Klagenfurt, Ritter, 2008.

PREISENDANZ, Wolfgang; Warning, Rainer. Das Komische. München, Wilhelm Fink, 1976.

SCHMÖLZER, Hilde. Gespräch mit Wolfgang Bauer. In: SchMÖLZER, Hilde. Das böse Wien. Gespräche mit österreichischen Künstlern. München, Nymphenburger Verlag, 1973, p. 39-52.

SIHLER, Horst Dieter. Eine ,Fieberkopf-Debatte. Der Standard. 19 de outubro de 2019. https://www.derstandard.at/story/2000110067521/handke-und-serbienpublikumsbeschimpfung-einst-und-jetzt. (20/10/2019).

WAGGERSHAUSER, Horst. Sumpftanzen: Zur komischen Avantgarde bei Wolfgang Bauer. München, edition text + kritik, 2016.

WIRTH, Uwe. Diskursive Dummheit: Abduktion und Komik als Grenzphänomene des Verstehens. Heidelberg, Winter, 1999. 